\title{
Spatial Distribution of the Rural Development Programme in Relation to Population Retention between 2015 and 2019
}

\author{
Csaba SZABÓ \\ PhD student \\ Hungarian University of Agriculture and Life Sciences, Gödöllø - Hungary \\ e-mail: szabocsa92@gmail.com
}

\begin{abstract}
The common agricultural policy accounts for more than $38 \%$ of the European Union's budget. In the 2014-2020 cycle, 8.9 billion euros went in Hungary to the first pillar and 4.1 billion euros to the second pillar for rural development, the mobilization of which was coordinated by the Rural Development Programme. The second pillar of the Common Agricultural Policy plays an important role in catching up with the lagging and depopulated Hungarian countryside. It serves key objectives such as sustainable environmental management, strengthening and diversifying the rural economy, or a fair standard of living. In my dissertation, I explore the territorial distribution of the payments of the rural development programme between 2015 and 2019 and how it affects unemployment and incomes.
\end{abstract}

Keywords: payments, development programme, income, unemployment, spatial distribution

\section{Introduction}

In the 2007-2013 programming period, Hungary prepared its first rural development programme within the Common Agricultural Policy of the European Union, which contains a set of instruments for the agricultural priorities of the community. The New Hungary Rural Development Programme was used to schedule and draw on the resources of the European Agricultural Fund for Rural Development. Grant items were identified along four priority axes. The first was to improve the competitiveness of agriculture and forestry, and the second was to preserve environmental sustainability and landscape character. The third axis was aimed at improving the quality of life in rural areas, making economic activities more colourful, and the fourth aimed at improving local employment and diversification. 
At the end of the cycle, all payments will be drawn only by 2015 . In the meantime, an agricultural policy for rural development from 2014 to 2020, based on the new foundations, began to be called the Rural Development Programme (RDP). Compared to its predecessor, grants can already be applied for via tenders. I would like to present the territorial distribution of the new programme and to get an answer to my hypothesis that these development resources contribute to the population retention force and the strengthening of regional incomes.

\section{Theoretical Background}

\section{District System}

According to Dr Mihály Burai, the district system is an important stage in the transformation of the territorial administration, the formation of the Good State, which appeared conceptually in the process of administrative policy strategic planning. After the abolition of districts dating back hundreds of years in 1983, the re-introduction of 'reinterpreted', geographically delimited territorial units aimed at the more efficient operation of the Hungarian administrative system. In the spirit of modern public administration, the district system has become an important institutional player in creating efficiency. At the same time, efficiency is not the only determining factor in the renewal of the territorial administration, as cost-saving and customer-oriented service provider attitudes are still requirements in the detailed rules of district design. As of 1 January 2013, district offices were established in Hungary as new administrative bodies, so the counties of Hungary would be divided into districts again after a 29-year break. Unlike before, the competence of district offices extends to all cities and villages, and in Budapest there are district offices with similar tasks in each district. Based on Urbánné Malomsoki et al. (2013), the districts started operating on 1 January 2013. Their organizational units are the district offices. 175 districts and 23 districts of the capital were established. Districts are the smallest territorial units of public administration operating within the system of government agencies. The seat of the district office is in the city designated as the seat of the district (Urbánné Malomsoki et al. 2013).

Based on the regional development and spatial planning objectives, the government organized the districts into three groups according to their beneficiaries. When classifying districts according to territorial development, it is necessary to take into account a complex indicator formed by social and demographic, housing and living conditions, local economy and labour market, as well as infrastructure and environmental indicators (four groups of indicators) (290/2014. (XI. 26.) Regulation, 2014). 
1. Districts to be developed: within the beneficiary districts, those districts with the lowest complex indicator in which $15 \%$ of the cumulative population of the country live;

2. Beneficiary districts: districts with a complex indicator less than the average of the complex indicators of all districts;

3. Districts to be developed with a complex programme: within the beneficiary districts, those districts with the lowest complex indicator in which $10 \%$ of the country's cumulative population live.

\section{Special Features of RDP}

Within the Common Agricultural Policy, subsidies are divided into two pillars. The first pillar has been widely criticized for its interventionist, market-regulating policy and non-productivity-generating income replacement, leading to growing debate around it. Throughout its long history, the CAP accounts for almost $40 \%$ of the EU budget, with Pillar I accounting for $74 \%$. We can say that the CAP system and its reforms are a strong buffer zone within the EU. Farmers prefer first-pillar direct payments, while others favour second-pillar rural development schemes that focus on the environment. The CAP reforms of recent decades have consistently led to a reduction in the overall budget, including a reduction in direct payments and an increase in the financial envelope of the second pillar. It has been calculated that the loss of Pillar II would lead to a $3.45 \%$ decrease in revenue for the more developed or more productive Member States, while a loss of 6.07 for the less developed countries such as Hungary. The loss of direct subsidies would affect the host society more severely than the loss of a possible second pillar, but in my view both are essential for catching up (Kiryluk-Dryjksa-Baer-Nawrocka 2019). In their study, Gohin and Zheng (2020) examine the impact of a measure halving direct payments. Production volume would show a negligible decrease $(0.18 \%)$ with a slight increase in prices. $\$ 1,329$ million would fall out of farmers' pockets, with negative welfare effects for European farmers. The non-farming European population and the US would be where there would be a slight increase in economic prosperity. In my opinion, this policy intervention, in particular the additional concentration of land on large estates, would lead to a reduction in the number of people living in the countryside and a decline in healthy food and short supply chains.

In addition to direct support, Bojnec and Fertô have also examined the effects of second-pillar rural development support at the NUTS 3 regional level in Hungary and Slovenia. An econometric and regression analysis explores the relationships between each pillar and the economic and social indicators it chooses. With regard to Pillar II, it has been noted that in Slovenia there is no correlation between employment data on family farms and rural development support, and paid workforce is further reduced even in the less-favoured areas, but other rural development support has a positive 
effect. In Hungary, LFA subsidies and other rural development subsidies have a positive effect on the employment capacity of farms. The support of the second pillar is very important for the countryside but not for agricultural employment, which was also indicated by the low regression coefficient (Bojnec-Fertő 2021). No analysis has been carried out on rural development pillar support and the employment conditions of the rural population outside the agricultural sector.

The preparation of the Rural Development Programme is based on the national strategic development objectives set out in the Partnership Agreement, the draft National Development and Spatial Development Concept, and the National Rural Strategy. Each call for proposals was created along seven objectives, as the division by the previous item was rejected (Prime Minister's Office, 2014):

1. Preservation of the natural values and resources of our landscapes.

2. Diverse and viable agricultural production.

3. Food and food safety.

4. Providing the livelihood of rural economy, increasing rural employment.

5. Strengthening rural communities, improving the rural population's quality of life.

6. The overall objective of the strategy is to improve the population retention and the retention capacity of our rural areas through agricultural economics, rural development and environmental developments and interventions.

7. The strategic and professional goals of the strategy are considered during the planning of the RDP when selecting the national priorities and emphases of the EAFRD priorities and focus areas.

The objectives of the Rural Development Programme were delimited along six themes, breaking with the previous four (competitiveness, rural development, environment, and LEADER) priority axes (Reszkető 2015):

1. Knowledge transfer and innovation (Knowledge transfer 7 pcs + Innovation 2 pcs);

2. Agricultural production and food processing (Investments 7 pcs + Risk management and income stabilization 3 pcs + Environmental management 10 pcs + Quality systems and producer groups 3 pcs);

3. Forest management (Investment 8 pcs + Environmental management 3 pcs);

4. Development of rural areas (Local economic development 4 pcs + Local infrastructure and service development 3 pcs + LEADER 4 pcs);

5. Young farmer (2 pcs);

6. Short supply chain (2 pcs).

Countries of the European Union, the Member States, have the option to move money from one pillar to the other, up to a maximum of $15 \%$. Most countries choose to move money from the first pillar to the second one; only five countries have chosen to transfer money from Pillar 2 to Pillar 1. So, on balance, almost 4 billion euros will be transferred from Pillar 1 to Pillar 2 during the 2014-2020 period. The European 
Agricultural Fund for Rural Development (EAFRD), which is the funding instrument of the second pillar of the Common Agricultural Policy of the European Union and one of the European Structural and Investment Funds, aims at strengthening the EU's agriculture, forestry sector, and rural areas in general (Financial Instruments, 2015). The Rural Development Programme (RDP) for Hungary was formally adopted by the European Commission on 10 August 2015 and last modified on 9 September 2019, outlining Hungary's priorities for using the 3.4 billion euros of EU budget money that is available for the 7-year period of 2014-2020 (European Commission 2019). Data on the amounts paid for the calls for proposals of the rural development programme were available to me for the period of 2015-2019. The selection of the CAP alternative measures by each Member State delays usually the start of the CAP implementation by one or two years. Member States have to construct their own CAP based on the EU CAP framework and choose from the different alternatives in order to adapt the CAP to their own requirements and environments, which is a really important aspect for agricultural sustainability (Mosquera-Losada et al. 2018). Based on the previous support methodology, i.e. the hand along the four axes, I systematized and grouped the payments of the calls for proposals. It also served to enable me to make a subsequent comparative analysis between the RDP and the New Hungary Rural Development Plan (NHRDP). I hypothesised that RDP payments have a linear effect on income and the unemployed, as objectives include priorities related to quality of life and increasing employment. In terms of territorial distribution, I believe that it focuses on the poorest areas of the country such as the Ózd area, Békés or Baranya County.

\section{Data and Methods}

During the spatial analysis, I examined at the district level which one is considered to be the LAU 1 territorial category according to the territorial statistical delimitation established by the European Union. Of the 175 districts established in 2013, Polgárd District was abolished by 2015, the area of which was annexed to Enying and Székesfehérvár districts. To set up more precise spatial relations, I excluded Budapest from the analysis, so I examined 173 districts. I requested the data on 2015-2019 from the Hungarian State Treasury, and then I aggregated them based on the axes of the previous cycle by merging the tender topics. Payments had not yet started in 2015, with most grants only starting in 2016 and data being available until 2019. Thus, I did not get the value of the amounts paid during the entire cycle. The four axes were subjected to a spatial autocorrelation analysis for the population. I also ran a summary analysis for the entire RDP, and I examined the effect of RDP on income and the unemployed using a linear regression analysis. By analysis of variance, I examined the correlation of district classifications by beneficiary in terms 
of resources. To run these methodological analyses, I used GEODA and IBM SPSS, the former for map representation and autocorrelation and the latter for variance and regression analysis.

\section{Analysis of Variance}

Analysis of variance is a sample that explains a population that examines the effect of one or more independent variables on a dependent variable. It serves to explore the differences between population averages. ANOVA analysis of variance compares means with analysis of variance. The condition for performing the analysis is that the dependent variable must be measured at least on an interval scale. Another such factor is variance homogeneity, which means that the dependent variable must have the same standard deviation at different levels of the independent variable. The point is whether the independent variable has a detectable influence on the dependent. In our case, it is important to determine whether each district category is affected by the subsidies (Sajtos-Mitev 2007).

\section{Linear Regression}

The characterization of univariate linear regression is the relationship between an independent and a dependent variable along the regression line. The coefficient of determination, r2, shows how much the dependence on the independent variable explains the values of the dependent variable. If r2 approaches 0 , then the independent does not explain the dependent, whereas if it approaches 1, the correlation is high. If there is a significant correlation between the two variables, but $\mathrm{r} 2$ is small, it means that other factors also play a role in determining the dependent variable. The simplest regression relationship between two variables is characterized by a straight line, suggesting a strong relationship (Csallner 2015).

\section{Spatial Autocorrelation Analysis}

Local Moran's I shows the relationship of the study area with its neighbours, so in areas with high values in the neighbourhood Moran's I shows whether this is typical or different (low) in the study area, and vice versa (Tóth 2003). In the case of the square grid-based neighbourhood, the names of the concepts were given based on chess pieces and their steps: bastion, runner, and queen. In our case, all directly contacting, neighbouring neighbours are involved in the neighbourhood (Tóth 2014). Therefore, it serves to map the neighbourhood relations between territorial units. It shows which areas are similar and which are not. Depending on the magnitude of the value, the strength of the similarity changes in a straight line: if the number is possibly negative, no correlation can be detected. The magnitude 
of the values can be divided into two groups: high or low. Based on this, four values can come out due to the neighbourhood (Egri 2014).

1. High-High: Area units with high values for which the neighbourhood also has a high value;

2. High-Low: Area units with high values for which the neighbourhood has a low value;

3. Low-Low: Area units with low values where the neighbourhood also has a low value;

4. Low-High: Area units with low values for which the neighbourhood has a high value.

\section{Results}

\section{Variance}

Based on the significance level of the variance homogeneity, it can be said that the probability of agreement of variances within the group is only $0.1 \%$, so the condition of identity is not met. Degree of freedom is the value by which we get the sum of squares of the difference between and within groups. According to Levene's test (Table 1), the standard deviation homogeneity was also not met due to its high value. So, we can state that the primary category in the allocation of resources did not cover the category of beneficiary in the given district.

Table 1. Homogeneity of variance

\begin{tabular}{lccc}
\hline Levene Statistic & df1 & df2 & Sig. \\
\hline 5,557 & 3 & 170 & .001 \\
\hline & & \multicolumn{2}{c}{ Source: author's calculation, 2021 }
\end{tabular}

In the first column of Table 2, we can see the sum of squares of the deviations, which are the squares of the total deviation. The degree of freedom column shows the degrees of freedom. Test $\mathrm{F}$ is the ratio of the squared deviation within and between groups, but the significance value is important, which, if below 0.05 , is a reliable difference between the sub-averages of the categories.

Table 2. Anova

\begin{tabular}{lccccc}
\hline RDP/1,000 cap. & Sum of squares & df & Mean square & F & Sig. \\
\hline Between groups & 11,205 & 3 & 3,735 & 35,353 & .000 \\
\hline Within groups & 17,960 & 170 & .106 & & \\
\hline Total & 29,165 & 173 & & & \\
\hline
\end{tabular}




\section{Linear Regression RDP - Income}

Linear regression examines the strength of the relationship between numerical variables, i.e. how strong the correlation is between the independent and dependent variables. Considering the current situation, the correlation between the RDP / 1,000 capita and the Income / 1,000 capita indicator is medium $\left(R^{2}=0.006\right)$, which does not show a relationship.

Table 3. Model summary

\begin{tabular}{|c|c|c|c|c|c|c|c|c|c|}
\hline \multirow{2}{*}{ Model } & \multirow{2}{*}{$\mathbf{R}$} & \multirow{2}{*}{$\mathbf{R}^{2}$} & \multirow{2}{*}{$\begin{array}{c}\text { Adjusted } \\
\mathbf{R}^{\mathbf{2}}\end{array}$} & $\begin{array}{c}\text { Std. error } \\
\text { of the } \\
\text { estimate }\end{array}$ & $\begin{array}{c}\mathbf{R} \text { square } \\
\text { change }\end{array}$ & $\begin{array}{c}\mathbf{F} \\
\text { change }\end{array}$ & $\mathbf{d f 1}$ & df2 & $\begin{array}{c}\text { Sig. F } \\
\text { change }\end{array}$ \\
\hline 1 & .075 & .006 & .000 & 0.0796 & .000 & .015 & 1 & 172 & .000 \\
\hline
\end{tabular}

Source: author's calculation, 2021

In the scatterplot diagram (Figure 1) below, I plotted the relationship between RDP resources and income. It appears that the values are not explicitly scattered along the regression line. In terms of income, Budakeszi, Dunaújváros, Szekszárd, Putnok, and a few other districts have the highest value. On the support side, the districts of Kiskőrös, Vásárosnamény, Fehérgyarmat, and the areas with typically higher agricultural values and higher values are scored high. The districts of Gyál, Mór, Szeged, and Keszthely have the lowest per capita income and the smallest amount of support. The highest are in Tiszafüred, Pannonhalma, and Záhony.

\section{RDP - Unemployed}

Table 4 shows that the relationship between the Unemployed / 1,000 capita and the RDP / 1,000 capita indicator is weak $\left(\mathrm{R}^{2}=0.153\right)$, as it is below 0.3. It can be deduced from this that the ratio of the amount paid to the RDP to the number of the unemployed was not actually related.

Table 4. Model summary (RDP / 1,000 cap. - unemployed / 1,000 cap.)

\begin{tabular}{|c|c|c|c|c|c|c|c|c|c|}
\hline \multirow{2}{*}{ Model } & \multirow{2}{*}{$\mathbf{R}$} & \multirow{2}{*}{$\mathbf{R}^{2}$} & \multirow{2}{*}{$\begin{array}{c}\text { Adjusted } \\
\mathbf{R}^{2}\end{array}$} & \multirow{2}{*}{$\begin{array}{c}\text { Std. error } \\
\text { of the } \\
\text { estimate }\end{array}$} & $\begin{array}{c}\mathbf{R} \text { square } \\
\text { change }\end{array}$ & $\begin{array}{c}\mathbf{F} \\
\text { change }\end{array}$ & df1 & df2 & $\begin{array}{c}\text { Sig. F } \\
\text { change }\end{array}$ \\
\hline 1 & .391 & .153 & .148 & 0.3114 & .149 & .30 .172 & 1 & 172 & .000 \\
\hline
\end{tabular}

Source: author's calculation, 2021

From the Figure 2 diagram below, we can read that it is not possible to draw a regression line along which the individual districts would be scattered. In the worst case, there are passages located at the apex of the $\mathrm{Y}$ axis and close to the zero point of the $\mathrm{X}$ axis. I could mention Kazincbarcika, Ózd, Salgótarján, Bátonyterenye, Pásztó, 
or even Tiszavasvár. The districts of Csornai, Téti, Sopron, Bicskei, and Gyula are in the best position, where support is high and unemployment is low.

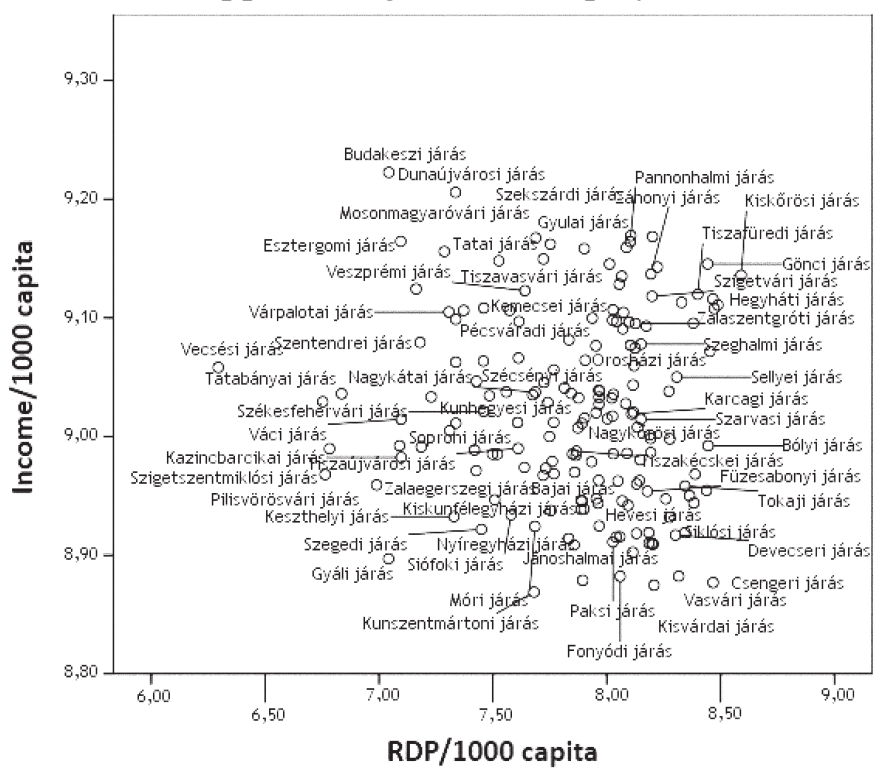

Source: author's creation, 2021

Figure 1. Distribution of income and RDP payments

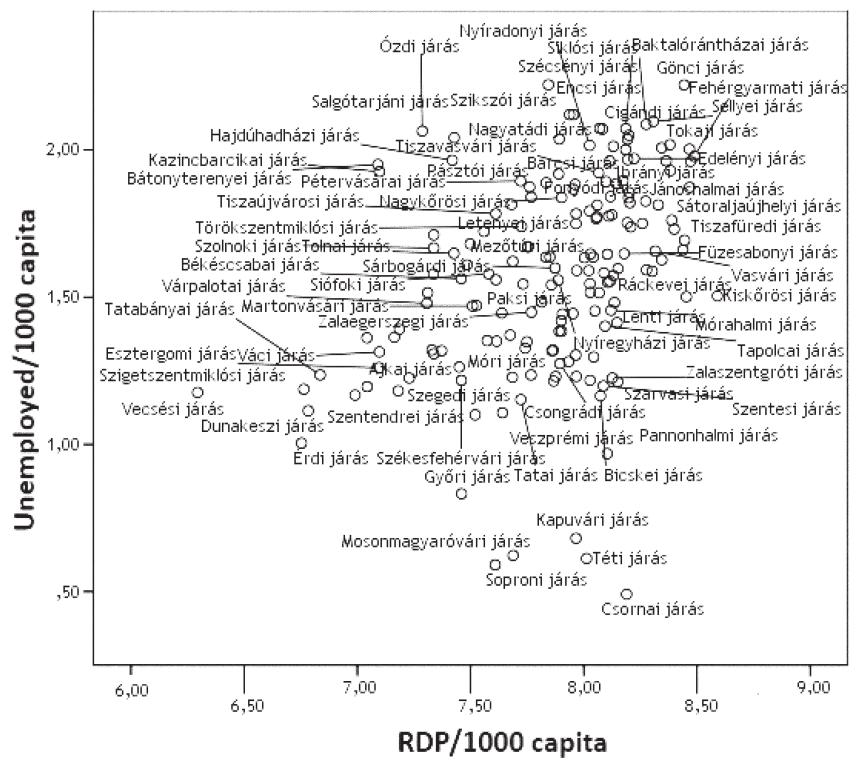

Source: author's creation, 2021

Figure 2. Distribution of the unemployed and RDP payments 


\section{Spatial Autocorrelation Analysis}

By performing the analysis, the districts were grouped based on their neighbourhood conditions. I ran this on all 4 axes as well as the total RDP. The data are divided into four categories based on their neighbourhood, which are clearly visible on the maps.

\section{Competitiveness Axis}

By accumulating the sum of the above-mentioned competitiveness titles, I created the database that forms the basis of the map shown here (Figure 3). The sources of competitiveness with high values in the Trans-Tisza region were in the districts of Vásárosnamény, Fehérgyarmat, Csenger, Mátészalka, Baktalórántháza, Hajdúböszörmény, and in the south in Hódmezővásárhely. In the Kecskemét, Kalocsa, and Jánoshalma districts between the Danube and the Tisza, the value of the given district and those around it is also high. It can be faintly shown that in a kind of north-east-south-west direction are those who have received the least from this form of support. From Pápa District to Salgótarján District, they did not primarily benefit from the rural development programme's competitiveness support, which is not due to their development or underdevelopment but mainly to their geographical location, as this axis is primarily aimed at developing agricultural production. Rarely are there districts where their own value is low but those of around them are higher, such as the districts of Makó, Kunszentmiklós, Kiskunhalas, and Tolna. To the north, the districts of Tiszavasvár, Hajdúhadház, and Kemecse also belong here.

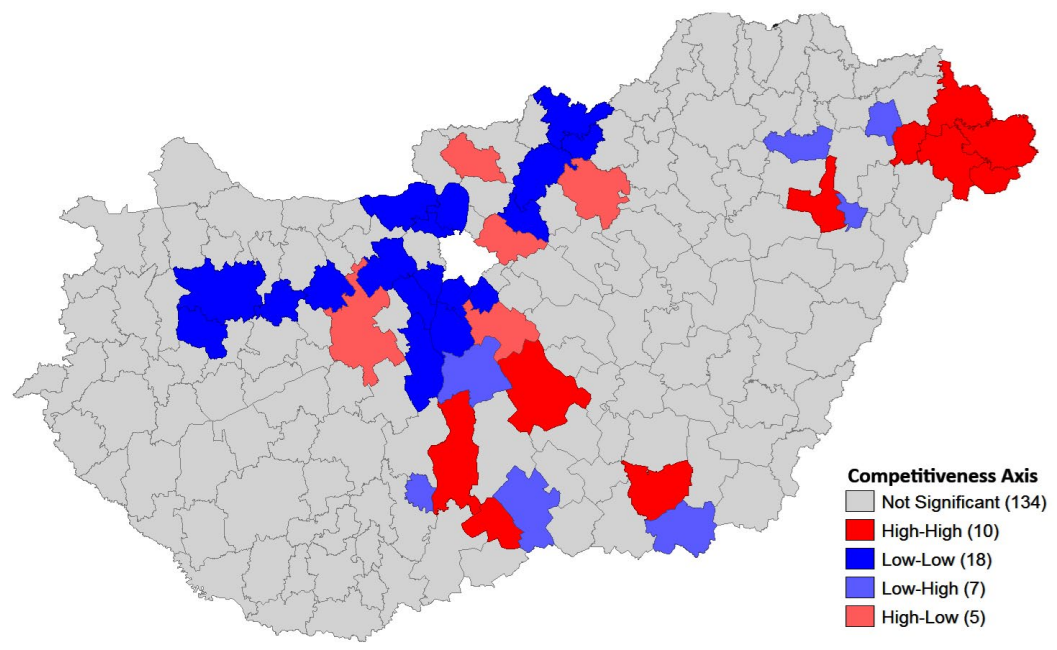

Source: author's creation, 2021

Figure 3. Distribution of the competitiveness axis payments 


\section{Rural Development Axis}

These efforts are not aimed primarily at developing agriculture but at the everyday lives of people living in the countryside and improving their quality of life. There are also eight districts that did not receive funds for rural development - these are mostly the Budapest metropolitan area and Várpalota District. The individual focal points where resources have been concentrated in development policy are clearly outlined. Four key integrations emerge, one of which is in the Borsod Basin, formed by the districts of Szikszó and Encs. The districts of Vásárosnamény, Csenger, Fehérgyarmat, Záhony, Kisvárda, Mátészalka, and Nyírbátor are not far from it, where the concentration of resources of the rural development axis is also high. In the eastern half of the country, there is another high-high cluster around Püspökladány and Berettyóúffalu. For the last major region, we need to look to the west of the country. One is in the territory of the country bordering Croatia, which consists of the districts of Siklós, Sellye, Barcs, Szigetvár, and Hegyhát. There are several districts around the otherwise beneficiary areas, which have a low value of their own, but the surrounding ones are high - these are the districts of Sárospatak, Tabi, Dombóvár, Bonyhád, Szentlőrinc, and Bóly. Rarely highlighted points in the country, such as Mezőkovácsháza and Pásztó, too, the Central Hungarian Region and its neighbours are typically not the main beneficiaries of the resources. There are two larger clusters among those with low-low neighbourhoods: in the east from Pétervásárai to Szarvasi and in the south in the Bicske, Veszprém, and Dunaújváros triangles.

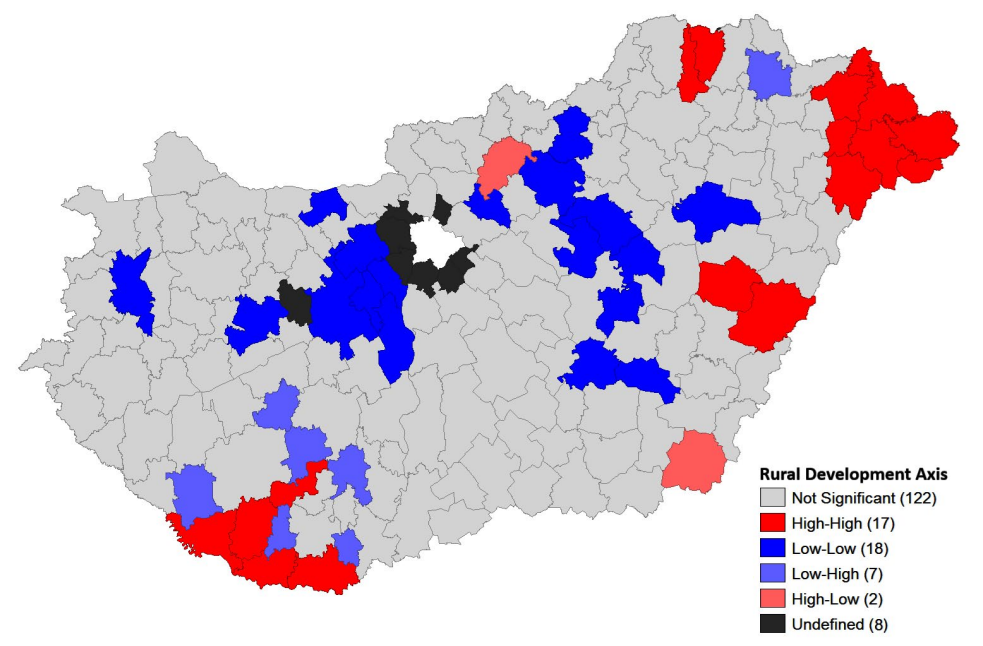

Source: author's creation, 2021

Figure 4. Distribution of the rural development axis payments 


\section{Environment Axis}

Under the third axis, the protection of the environment was supported during the development package. The protection of grasslands and forest areas, gene conservation and other environmental protection includes tender payments, which also greatly influences the territorial distribution. The map (Figure 5) below shows well which districts are the ones where larger sums have been paid in proportion to the population. A north-south line is nicely drawn in the area of the Great Plain, which starts above with the grassy steppe of Hortobágy, through Nagykunság and Nagy-Sárrét, all the way to the northern region of Viharsarok. These districts are Mezőcsát, Tiszafüred, Balmazújváros, Hajdúböszörmény, Hajdúszoboszló, Püspökladány, and Szeghalom. Another such high-high zones are the districts of Csenger, Fehérgyarmat, and Mátészalka or Kecskemét, Kiskőrös, Kiskunmajsa, Kunszentmiklós, and Kalocsa in Kiskunság. It has a low value from Tata to Ózd. There are also outstanding areas in themselves, where the value of the given district is high and that of the neighbours is low, such as the Bicske and Székesfehérvár districts. In the low-high value areas, i.e. where the own value is low but that of its neighbours is above average, there are districts as Derecskei, Baktalórántháza, Hajdúhadháza, Nagykőrös, Kiskunfélegyháza, Jánoshalma, and Téti.

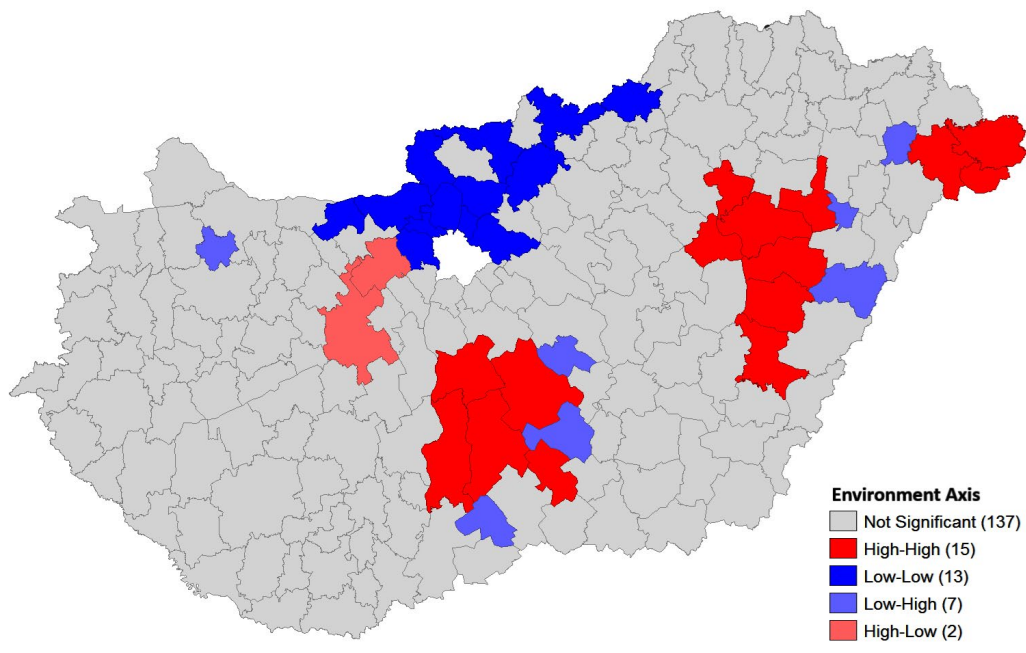

Source: author's creation, 2021

Figure 5. Distribution of the environment axis

\section{LEADER + HRN Axis}

LEADER + HRN (Hungarian Rural Network) is a community initiative that aims to put the principle of subsidiarity into practice, i.e. local people can have a say 
in the territorial distribution of resources. The areas are run by so-called LEADER Local Action Groups (LAGs), which do not have district status (administrative unit status), so a LAG has municipalities rather than districts. The Körös-Sárrét Rural Development Association, which includes 22 settlements, belongs to a development group that is part of Szeghalom District on the map. A significant part of the payments from the surrounding districts is concentrated in Szeghalom settlements because not the entire area of the surrounding districts belongs to the targeted, more backward settlements; therefore, in my opinion, their distribution should be examined most at the settlement level. There are even more significant districts, such as Miskolc and Eger, and significant areas on the western border of the country, in the Barcs, Marcali, and Tabi districts, and insular ones in the districts of Székesfehérvár and Tata. Six districts do not receive such payments at all.

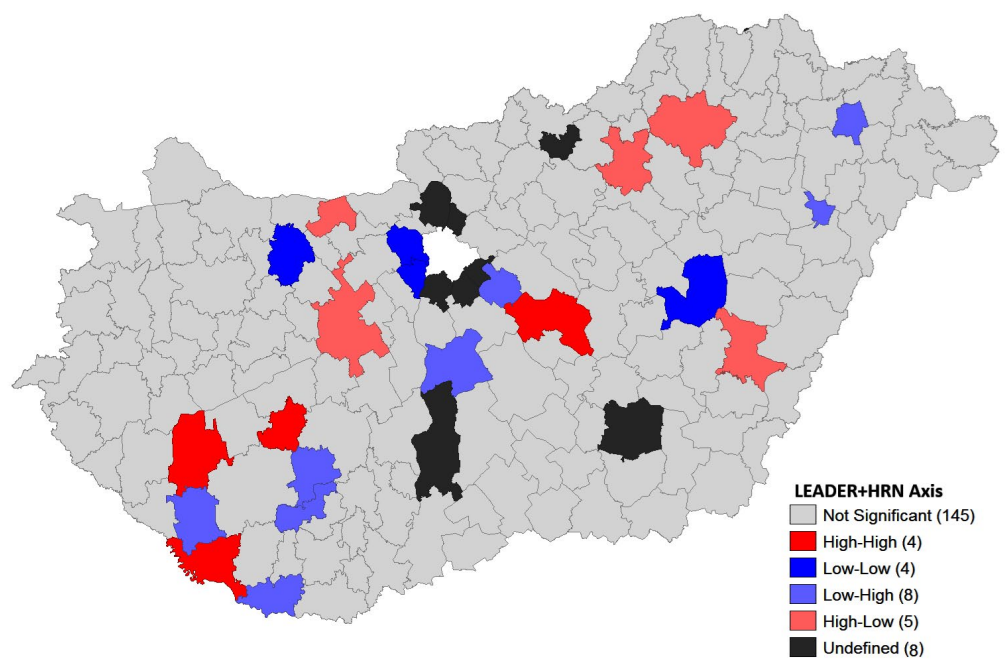

Source: author's creation, 2021

Figure 6. Distribution of LEADER + HRN axis

\section{Complete Rural Development Programme}

Figure 7 shows the territorial distribution of the amounts paid during the entire cycle of the Széchenyi 2020 Rural Development Programme, with the help of which the individual development nodes can be clearly seen. Based on their neighbourhood, the beneficiaries are the districts of Mátészalka, Csenger, Fehérgyarmat, Vásárosnamény, Kisvárda, Záhony, Cigánd, Sárospatak, Sátoraljaújhely, Gönc, and their surroundings; in Hortobágy, the districts of Balmazújváros, Hajdúszoboszló, Püspökladány, Karcag, and their surroundings and the area of Kalocsa District in Kiskunság. There are also scattered insular places where the indicator used for territorial distribution is as high as for Bicskei District or as low as for Kiskunhalas, 
Pécs, or Szentlőrinc. It is interesting that the lines of the motorways starting from Budapest stand out. To the east, there is the M3, to the south the M5, and to the west the M1 and M7. These areas have benefited less from RDP payments. In this context, it is interesting that Nógrád County is not exactly the target of the developments despite having significant economic and social problems.

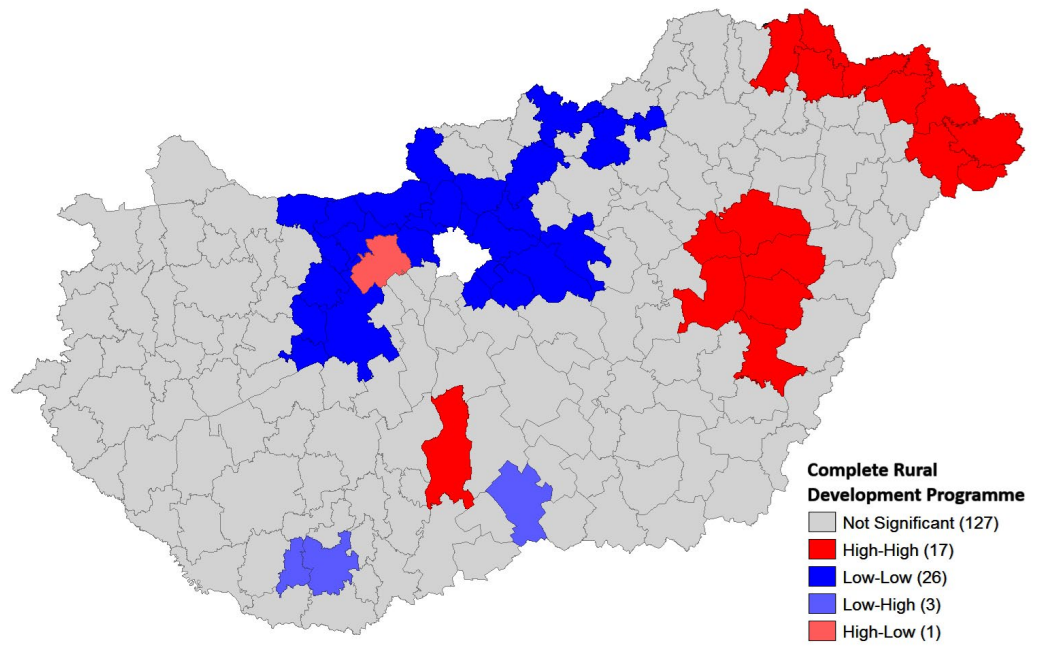

Source: author's creation, 2021

Figure 7. Complete rural development programme

\section{Conclusions}

I have come to the conclusion that there is no significant correlation between the amount of funds paid for rural development and the beneficiary classification. I looked at whether there was a link between income, the number of the unemployed, and RDP resources, as a result of which I found a weak correlation, i.e. subsidy amounts did not significantly affect unemployment and income developments, as they were also affected by many other factors, which confirms the findings of Bojnec and Fertô regarding the second pillar support of the CAP. There are significant differences between the four axes obtained after the aggregation of the RDP's topic groups, which is due to the area-specific directions; however, it can be stated that they did not focus on the Central Hungarian Region and its wider agglomeration. The sources of competitiveness fell mainly on Szabolcs-Szatmár-Bereg County and between the Danube and the Tisza. In terms of rural development, the area of Szabolcs, the areas of Baranya County, which are struggling with serious economic and social problems, and the Borsod Basin in the North Hungarian Mountains have also emerged. In connection with environmental protection claims, the 
most financed points from the EU fund are the central areas of the Great Plain, the Sár-meadow region, the districts of Kiskunság, and the fruit-growing region in the eastern part of Szabolcs-Szatmár-Bereg County. In terms of LEADER + HRN resources, only a few significant points emerge in a few larger districts. Regarding the entire RDP, the most interesting part is the low-subsidized one, which roughly follows the trace of the motorways spreading from Budapest.

My hypothesis was partially confirmed because I proved the existence of the relationship, although it is very weak and many other, more emphasized factors also have an impact on profitability and employment. The distribution confirmed that the districts of Baranya County are beneficiaries and some of Békés County are also beneficiaries. But, unfortunately, Ózd is not among the beneficiaries at all, which is quite surprising.

\section{References}

BOJNEC, Stefan-FERTŐ, Imre. 2022. Do Different Types of Common Agricultural Policy Subsidies Promote Farm Employment? Land Use Policy 112: 105823. https://doi.org/10.1016/j.landusepol.2021.105823.

CSALLNER, András Erik. 2015. Bevezetés az SPSS statisztikai programcsomag használatába. Szeged: Szegedi Tudományegyetem.

EGRI, Zoltán. 2014. Bevezetés az egészségi állapot általános és területi vizsgálataiba. Oktatási segédlet. Szarvas.

EGRI, Zoltán-KŐSZEGI, Irén Rita. 2018. A gazdasági-társadalmi (komplex) térszerkezet kelet-közép-európai képe. Területi Statisztika 58(1): 27-56. DOI: 10.15196/TS580102.

EGRI, Zoltán-TÖRŐCSIK, Viktória-TÁNCZOS, Tamás. 2009. Regional HDI as a Territorial and Social Differentiation Index in Central Europe. In: Káposzta, József (ed.), New Elements and Research in Spatial Economy. Komárno: Research Institute of J. Selye University. 167-180.

GOHIN, Alexandre-ZHENG, Yu. 2020. Reforming the European Common Agricultural Policy: From Price \& Income Support to Risk Management. Journal of Policy Modeling 42(3): 712-727.

KÁPOSZTA, József. 2016. Regionális összefüggések a vidékgazdaság fejlesztésében. Studia Mundi - Economica 3(1): 52-61.

KIRYLUK-DRYJSKA, Ewa-BAER-NAWROCKA, Agnieszka. 2019. Reforms of the Common Agricultural Policy of the EU: Expected Results and Their Social Acceptance. Journal of Policy Modeling 41(4): 607-622.

KOVÁCS, András Dónát-FARKAS, Jenő Zsolt-PERGER, Éva. 2015. A vidék fogalma, lehatárolása és új tipológiai kísérlete. Tér és Társadalom 29(1): 11-34. DOI:10.17649/TET.29.1.2674. 
MINISZTERELNÖKSÉG. 2014. Magyarország - Vidékfejlesztési Program 20142020. https://www.palyazat.gov.hu/node/56582\#.

NEWBY, Howard. 1980. Trend Report: Rural Sociology. Current Sociology 28(1): 3-109. https://doi.org/10.1177/001139218002800102.

1985. 25 Years of Rural Sociology. Sociologia Ruralis 25(3-4): 207-213. https:// doi.org/10.1111/j.1467-9523.1985.tb00762.

RESZKETŐ, Tímea. 2015. Vidékfejlesztési Program Kézikönyv. Budapest: Nemzeti Agrárgazdasági Kamara.

SAJTOS, László-MITEV, Ariel. 2007. SPSS Kutatási és adatelemzési kézikönyv. Budapest: Alinea.

TÓTH, Géza. 2003. Területi autokorrelációs vizsgálat a Local Moran I módszerével. Tér és Társadalom XVII(4): 39-49.

2014. Térinformatika a gyakorlatban közgazdászoknak. Miskolc: Miskolci Egyetem.

URBÁNNÉ MALOMSOKI, Mónika-NAGYNÉ PÉRCSI, Kinga-SZABÓ, Virág. 2013. A járási rendszer és az átalakított önkormányzati feladat ellátási struktúra kialakításának hatása a településekre. In: Lukovics, Miklós-Savanya, Péter (eds), Új hangsúlyok a területi fejlödésben. Szeged: JATEPress. 261-279.

*** 290/2014 (XI. 26.). Kormányrendelet a kedvezményezett járások besorolásáról. 